\title{
Prognostic impact of serum transthyretin in patients with non-small cell lung cancer
}

\author{
TATSUO SHIMURA $^{1}$, MASAHIKO SHIBATA ${ }^{2}$, TAKUYA INOUE ${ }^{3}$, YUKI OWADA-OZAKI ${ }^{3}$, TAKUMI YAMAURA ${ }^{3}$, \\ SATOSHI MUTO ${ }^{3}$, TAKEO HASEGAWA ${ }^{3}$, YUTAKA SHIO ${ }^{3}$ and HIROYUKI SUZUKI ${ }^{3}$
}

Departments of ${ }^{1}$ Progressive DOHaD Research, ${ }^{2}$ Advanced Cancer Immunotherapy and ${ }^{3}$ Chest Surgery, Fukushima Medical University, Fukushima 960-1295, Japan

Received October 24, 2018; Accepted March 27, 2019

DOI: $10.3892 / \mathrm{mco} .2019 .1837$

\begin{abstract}
The identification of novel biomarkers is of great importance for improving the outcome of patients with non-small cell lung cancer (NSCLC). Therefore, the aim of the present study was to determine whether the serum transthyretin (TTR) level could be used as a novel prognostic biomarker for patients with NSCLC. Serum TTR levels, and nutritional and inflammatory parameters were examined prior to treatment in 42 patients with NSCLC. Candidates for independent predictors of prognostic factors were subjected to univariate and multivariate analyses using a Cox proportional hazard model. IL-12-productivity, serum retinol binding protein, albumin and transferrin levels, and lymphocyte-to-monocyte ratio were significantly lower in the patients with TTR $<22 \mathrm{mg} / \mathrm{dl}$ than those in the patients with TTR $\geq 22 \mathrm{mg} / \mathrm{dl}$. Patients with serum TTR levels of $<22 \mathrm{mg} / \mathrm{dl}$ exhibited a poorer overall $(\mathrm{P}=0.008)$ and recurrence-free survival $(\mathrm{P}=0.027)$ when compared with those with serum TTR levels of $\geq 22 \mathrm{mg} / \mathrm{dl}$. The parameters, $\geq \mathrm{T} 2$ and age $\geq 75$ years were independent prognostic factors for overall survival, and TTR $<22 \mathrm{mg} / \mathrm{dl}$ and $\geq \mathrm{T} 2$ were independent prognostic factors for recurrence-free survival. In conclusion, anthropometric measurement of serum TTR, as well as $\mathrm{T}$ category, can be useful for predicting the 5-year recurrence-free survival of patients with NSCLC.
\end{abstract}

Correspondence to: Professor Tatsuo Shimura, Department of Progressive DOHaD Research, Fukushima Medical University, 1 Hikarigaoka, Fukushima 960-1259, Japan

E-mail: tshimura@fmu.ac.jp

Abbreviations: NSCLC, non-small cell lung cancer; GPS, Glasgow prognostic score; CRP, C-reactive protein; TTR, transthyretin; $\mathrm{RBP}$, retinol binding protein; TF, transferrin; WBC, white blood cell count; NLR, neutrophil-to-lymphocyte ratio; LMR, lymphocyte-to-monocyte ratio; CEA, carcinoembryonic antigen; IL, interleukin; RPMI, Roswell Park Memorial Institute media

Key words: non-small cell lung cancer, transthyretin, prealbumin, malnutrition, prognosis

\section{Introduction}

Lung cancer is the leading cause of cancer death worldwide, accounting for $19.4 \%$ of cancer deaths in adults (1). It is essentially divided into two types: Small-cell lung cancer (approximately 15\%) and non-small cell lung cancer (NSCLC) (approximately 85\%). Despite advances in early detection and standard treatment, NSCLC is still often diagnosed at an advanced stage and has a poor prognosis (2).

In search of a biomarker to predict the prognosis of NSCLC patients, there has been accumulating evidence reported of the usefulness of inflammation- or nutritional factor-based prognostic scores, such as the Glasgow prognostic score (GPS) based on C-reactive protein (CRP) and albumin (3). Previously, we reported significance of the high-sensitivity modified GPS in patients with resectable NSCLC (4). However, as these scoring systems require calculation using several variables, a simpler preoperative prognostic biomarker is needed.

Transthyretin (TTR), also known as prealbumin, has a relatively short half-life (approximately two days), and is the earliest laboratory indicator of malnutrition status because it contains a high percentage of essential amino acids (5). TTR correlates with patient outcome in various diseases (6-8). With regard to lung cancer, TTR has been reported to be useful in distinguishing lung cancer from lung infection (9), and to be synthesized in lung cancer cells (10). Low perioperative serum TTR was reported to predict early recurrence after curative-intent surgery in NSCLC patients (11). Although Alifano et al (12) reported that TTR was useful to predict prognosis of NSCLC patients in relation to CRP and CD8+ lymphocyte, its prognostic value remains to be determined. Thus, we sought to examine the preoperative prognostic impact of serum TTR in patients with NSCLC in relation to other nutritional and inflammatory factors.

\section{Patients and methods}

Study population. Forty-two NSCLC patients were prospectively enrolled between September, 2011 and September, 2012 (25 men and 17 women, mean age 68.3 ; range 50 to 85 years, 24 patients with adenocarcinoma and 18 patients with squamous cell carcinoma). Patient characteristics are summarized in Table I. Among these, 35 patients underwent curative-intent surgery. Following 
surgery, cancer stage of the patients was determined pathologically according to the TNM classification system of malignant tumors published by the Union for International Cancer Control, eighth edition (13). All operated patients underwent lobectomy with lymphadenectomy without preoperative chemotherapy or radiotherapy. Adjuvant chemotherapy was performed on eight out of the 35 operated patients. The study protocol was approved by the Ethics Committee of Fukushima Medical University (Fukushima, Japan; approval no. 1095) and written informed consent was obtained from the enrolled patients.

Measurements of TTR and other parameters. Blood samples were collected before treatment initiation. Patient nutritional status was determined by measuring the serum concentrations of total protein, albumin, retinol binding protein (RBP), TTR, and transferrin (TF). These parameters were measured at the Central Clinical Laboratory of Fukushima Medical University Hospital. As for the inflammatory parameters, CRP, white blood cell count (WBC), neutrophil, lymphocyte and monocyte counts, as well as neutrophil-to-lymphocyte ratio (NLR) and lymphocyte-to-monocyte ratio (LMR), were used. With regard to tumor markers, carcinoembryonic antigen (CEA) (40 patients) and cytokeratin-19 fragment (38 patients) were evaluated. Squamous cell carcinoma antigen was tested when a patient had squamous cell carcinoma (17 out of the 18 patients with squamous cell carcinoma).

As for the immunological cytokines, the productivity of interleukin (IL)-10, 12, and 17 were examined. Peripheral blood mononuclear cells were separated on Ficoll-Hypaque (Pharmacia-Biotech, Uppsala, Sweden) columns, and washed twice with Roswell Park Memorial Institute media (RPMI)-1640 (Wako Pure Chemical Industries Ltd., Osaka, Japan). The isolated PBMCs were then incubated in one $\mathrm{ml}$ of RPMI-1640 at a concentration of $10^{6}$ cells $/ \mathrm{ml}$ with $10 \%$ heat-inactivated fetal calf serum (Gibco BRL, St. Louis, $\mathrm{MO}, \mathrm{USA}$ ) in $5 \% \mathrm{CO}_{2}$ at $37^{\circ} \mathrm{C}$ for $24 \mathrm{~h}$ with the following stimulations: $20 \mu \mathrm{g} / \mathrm{ml}$ phytohemagglutinin for IL-10 and IL-17 production assays, and $0.01 \%$ of Staphylococcus aureus cowan-1 for IL-12 production assays. Aliquots of these supernatants were then frozen and stored at $-80^{\circ} \mathrm{C}$ until use. Supernatant samples were subsequently thawed and used for the measurement of IL-10, IL-12, and IL-17 concentrations using enzyme-linked immunosorbent assay (R\&D Systems, Minneapolis, MN, USA). Each sample was used only once after thawing, and not all blood samples were of sufficient volume for all measurements.

Statistical analysis. Data are presented as frequencies or percentages for categorical variables and mean \pm standard deviation for continuous variables, unless otherwise indicated. For categorical clinical variables, differences between two groups were evaluated by chi-square test or Fisher's exact test. The differences in mean values between the groups were analyzed using the Mann-Whitney $U$ test. One-way analysis of variance was used for comparisons of variables between more than two groups with Tukey's post hoc test for multiple comparisons. Associations between the two variables were quantified using Spearman's rank correlation coefficient.

With regard to survival analysis, the mean observation period was 67.9 months (range: 60.6-73.8). The final
Table I. Patient characteristics.

\begin{tabular}{|c|c|c|}
\hline Clinical characteristics & Total $\mathrm{n}$ & $\%$ \\
\hline \multicolumn{3}{|l|}{ Age, years } \\
\hline$<75$ & 27 & 64.3 \\
\hline$\geq 75$ & 15 & 35.7 \\
\hline \multicolumn{3}{|l|}{ Sex } \\
\hline Male & 25 & 59.5 \\
\hline Female & 17 & 40.5 \\
\hline \multicolumn{3}{|l|}{ Histology } \\
\hline Adeno & 24 & 57.1 \\
\hline Squamous & 18 & 42.9 \\
\hline \multicolumn{3}{|l|}{$\mathrm{T}$} \\
\hline $1 \mathrm{a}$ & 0 & 0.0 \\
\hline $1 b$ & 13 & 31.0 \\
\hline $1 \mathrm{c}$ & 13 & 31.0 \\
\hline $2 \mathrm{a}$ & 6 & 14.3 \\
\hline $2 b$ & 5 & 11.9 \\
\hline 3 & 3 & 7.1 \\
\hline 4 & 2 & 4.8 \\
\hline \multicolumn{3}{|l|}{$\mathrm{N}$} \\
\hline 0 & 27 & 64.3 \\
\hline 1 & 4 & 9.5 \\
\hline 2 & 9 & 21.4 \\
\hline 3 & 2 & 4.8 \\
\hline \multicolumn{3}{|l|}{$\mathrm{M}$} \\
\hline 0 & 40 & 95.2 \\
\hline 1 & 2 & 4.8 \\
\hline \multicolumn{3}{|l|}{ Stage } \\
\hline $\mathrm{I}$ & 21 & 50.0 \\
\hline II & 9 & 21.4 \\
\hline III & 10 & 23.8 \\
\hline IV & 2 & 4.8 \\
\hline
\end{tabular}

Adeno, adenocarcinoma; Squamous, squamous cell carcinoma; $\mathrm{T}$, tumor; $\mathrm{N}$, node; $\mathrm{M}$, metastasis

assessment of disease status was made on September 30, 2017. The overall survival rate was calculated using the Kaplan-Meier method and differences between the groups were assessed using the log-rank test. The TTR cutoff value for evaluation as a prognostic factor was set at $22 \mathrm{mg} / \mathrm{dl}$ according to its normal range $(\geq 22 \mathrm{mg} / \mathrm{dl}$ ) at our institution. According to our previous study (4) the albumin, CRP and NLR cutoff values, were set at $3.5 \mathrm{~g} / \mathrm{dl}, 0.3 \mathrm{mg} / \mathrm{dl}$ and 4.5 , respectively. Prognostic factor candidates were subjected to univariate and multivariate analysis using a Cox proportional hazard model to identify independent predictors of prognosis. When a P-value of a factor was under 0.05 in the univariate analysis, the factor was also analyzed in the multivariate analysis. A two-sided $\mathrm{P}<0.05$ was considered to indicate a statistically significant difference. All statistical calculations were performed using SPSS version 24 software (IBM, Corp., Armonk, NY, USA). 
A
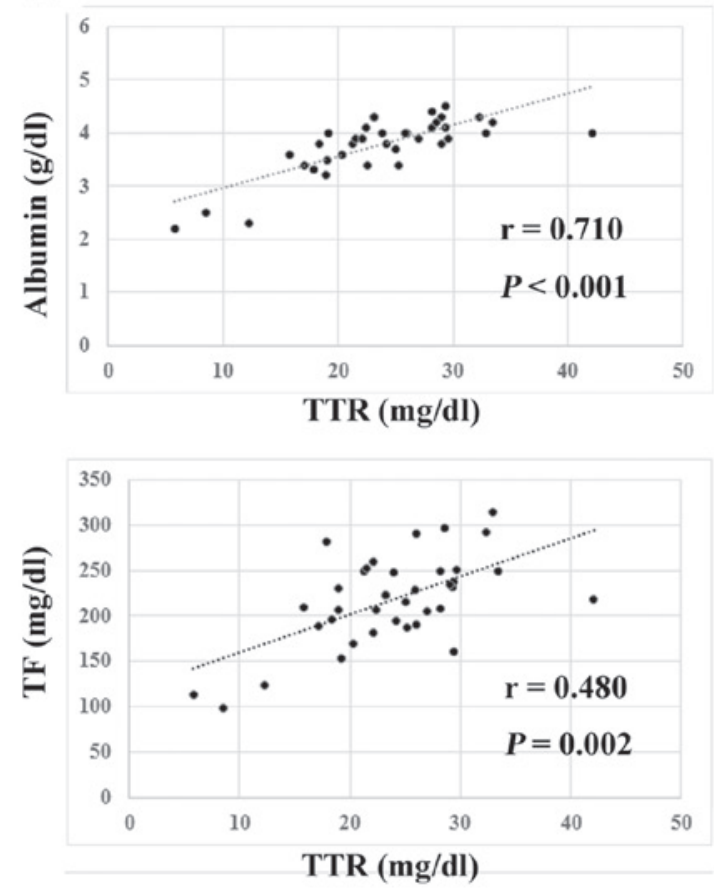

B
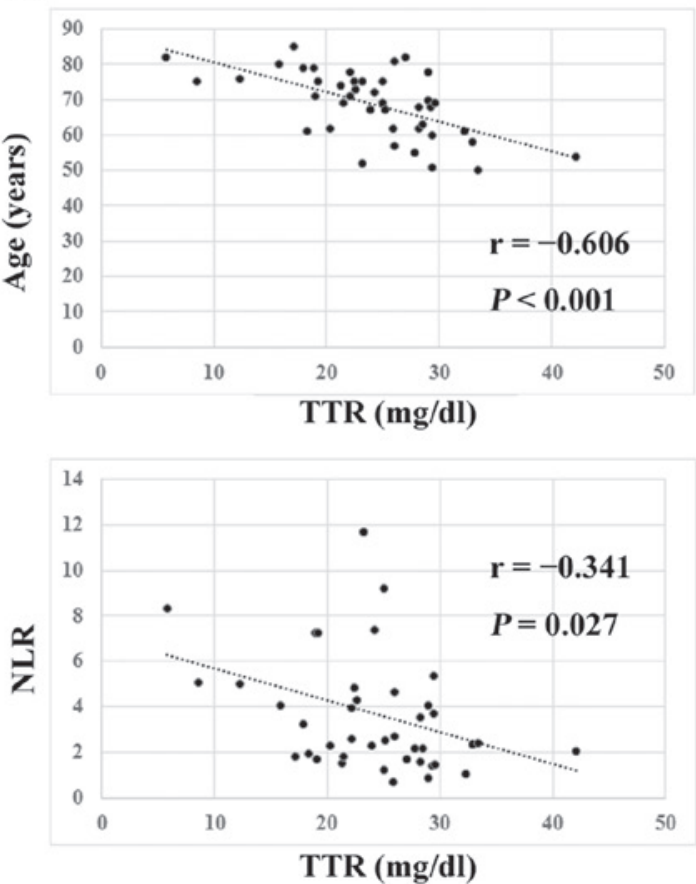
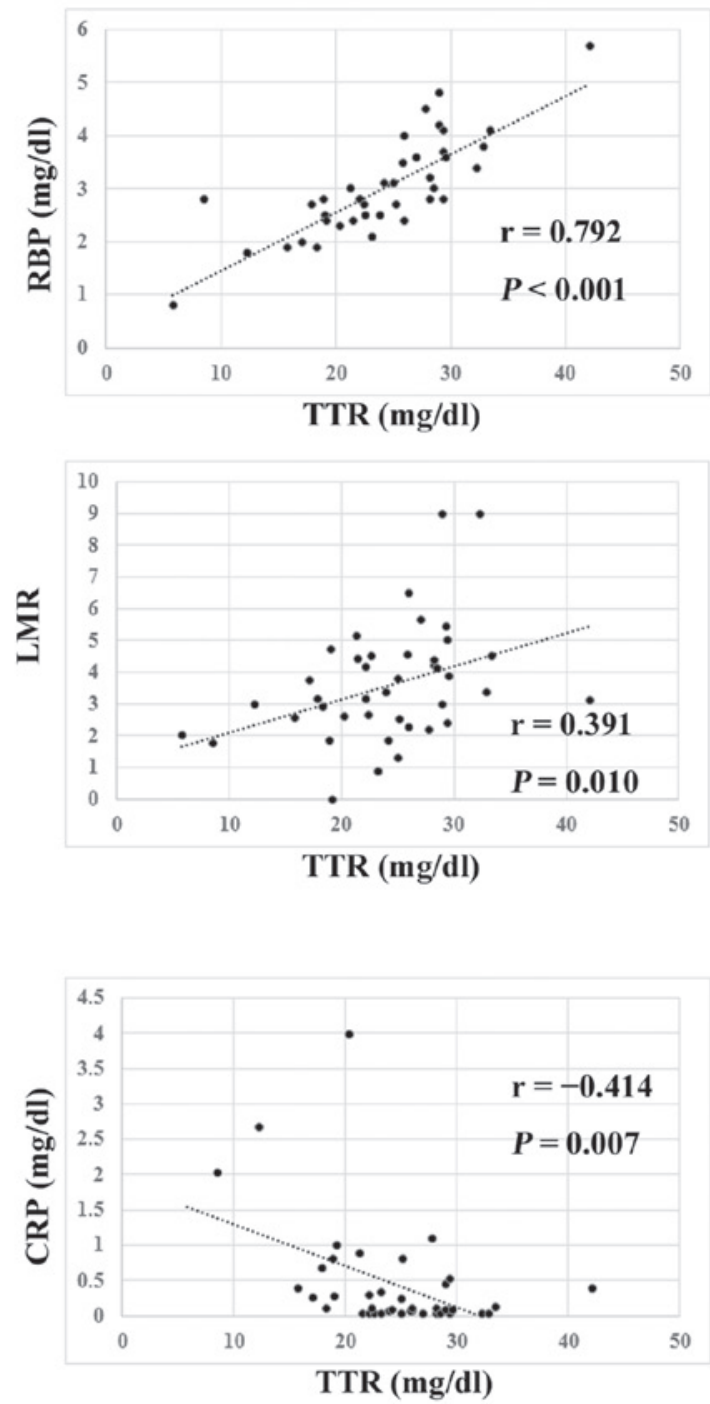

Figure 1. Transthyretin correlation. (A) Serum transthyretin levels exhibited significant correlations with serum albumin ( $\mathrm{r}=0.710$, $\mathrm{P}<0.001)$, RBP $(\mathrm{r}=0.792, \mathrm{P}<0.001)$, TF $(\mathrm{r}=0.480, \mathrm{P}=0.002)$ and LMR $(\mathrm{r}=0.391, \mathrm{P}=0.010)$. (B) Serum transthyretin levels exhibited significantly inverse correlations with age $(r=-0.606, P<0.001), C R P(r=-0.414, P=0.007)$ and NLR ( $r=-0.341, P=0.027)$. TTR, transthyretin; RBP, retinol binding protein; TF, transferrin; LMR, lymphocyte-to-monocyte ratio; CRP, C-reactive protein; NLR, neutrophil-to-lymphocyte ratio.

\section{Results}

Relationship between TTR and clinicopathological features. As shown in Fig. 1, serum TTR levels exhibited significant correlations with serum albumin $(\mathrm{r}=0.710, \mathrm{P}<0.001), \mathrm{RBP}$ $(\mathrm{r}=0.792, \mathrm{P}<0.001), \mathrm{TF}(\mathrm{r}=0.480, \mathrm{P}=0.002)$ and $\mathrm{LMR}(\mathrm{r}=0.391$, $\mathrm{P}=0.010)$, but also showed significantly inverse correlations with age $(\mathrm{r}=-0.606, \mathrm{P}<0.001), \mathrm{CRP}(\mathrm{r}=-0.414, \mathrm{P}=0.007)$ and NLR
( $\mathrm{r}=-0.341, \mathrm{P}=0.027)$. When TTR levels were compared with $\mathrm{T}$ categories (T4 was excluded due to its small number), T categories had a statistically significant effect on TTR levels using one-way ANOVA $\{\mathrm{F}(2,37)=6.533, \mathrm{P}=0.004\}$ (Fig. 2A). In an analysis of the post hoc test using Turkey's method, TTR levels of the patients with $\mathrm{T} 3$ showed statistically lower than those with $\mathrm{T} 1(\mathrm{P}=0.003)$ or $\mathrm{T} 2(\mathrm{P}=0.005)$. In addition, IL-12-productivity, serum RBP, albumin and TF levels, and LMR were significantly 
A

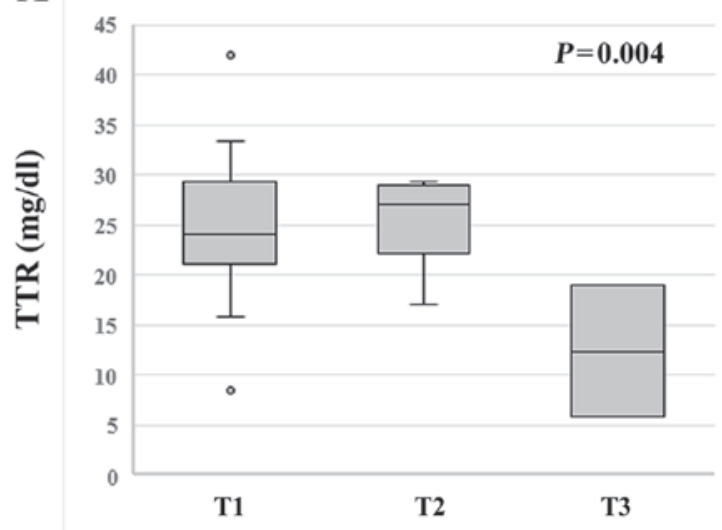

B
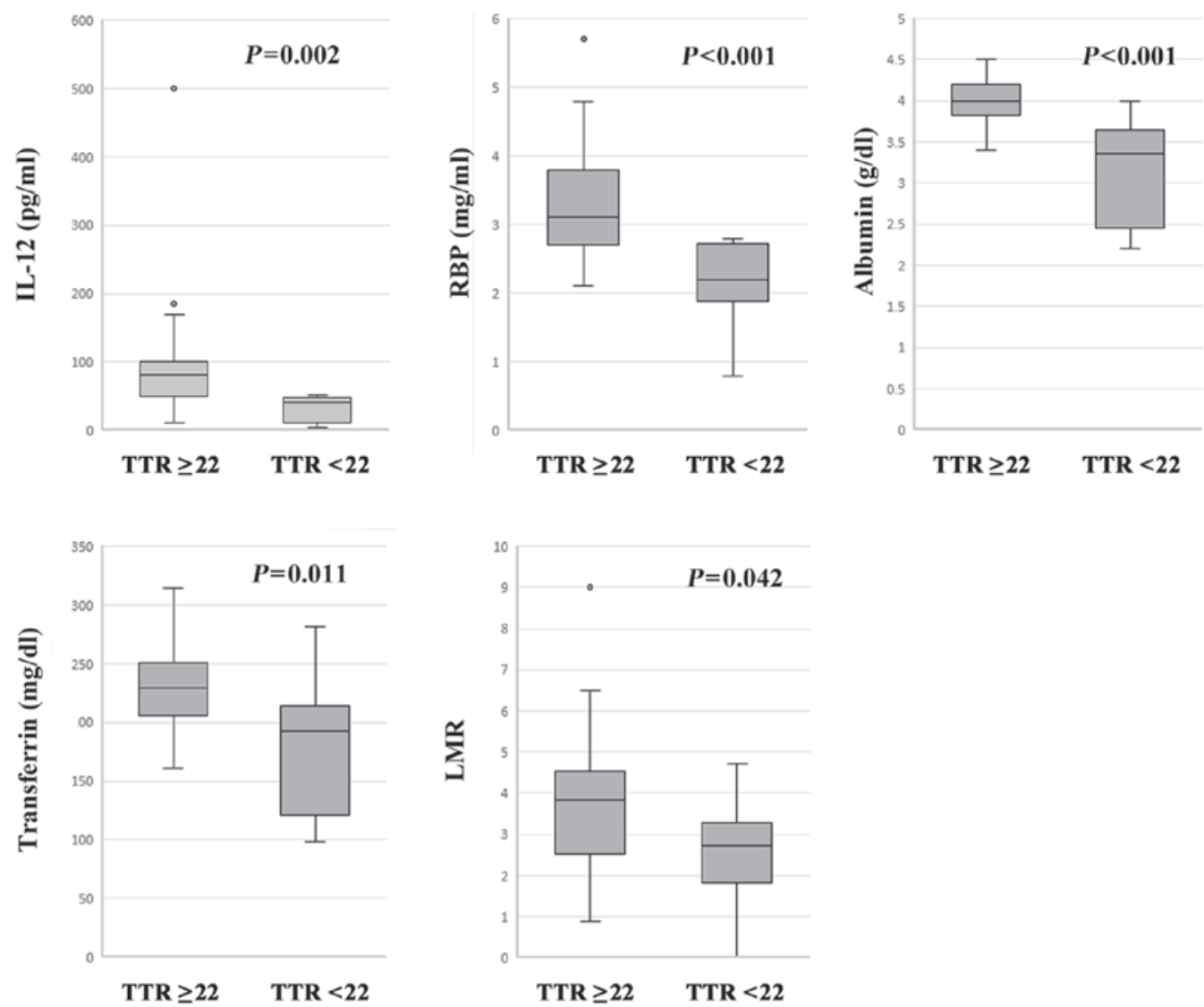

Figure 2. Associations between serum TTR and clinicopathological features. (A) When the TTR levels were compared with T categories (T4 was excluded due to its small number), the T categories were revealed to have a statistically significant effect on TTR levels as determined by one-way analysis of variance $\{\mathrm{F}(2,37)=6.533, \mathrm{P}=0.004\}$. Furthermore, following post hoc Tukey test comparisons, the TTR levels of the patients with T3 were significantly lower than those with $\mathrm{T} 1(\mathrm{P}=0.003)$ or $\mathrm{T} 2(\mathrm{P}=0.005)$. $(\mathrm{B})$ IL-12-productivity $(\mathrm{P}=0.002)$, serum $\mathrm{RBP}(\mathrm{P}<0.001)$, albumin $(\mathrm{P}<0.001)$ and transferrin levels $(\mathrm{P}=0.011)$ and LMR $(\mathrm{P}=0.042)$ were significantly lower in the patients with TTR $<22 \mathrm{mg} / \mathrm{dl}$ than those in the patients with TTR $\geq 22 \mathrm{mg} / \mathrm{dl}$. TTR, transthyretin; IL-12, interleukin-12; RBP, retinol binding protein; LMR, lymphocyte-to-monocyte ratio.

lower in the patients with TTR $<22 \mathrm{mg} / \mathrm{dl}$ than those in the patients with TTR $\geq 22 \mathrm{mg} / \mathrm{dl}$ (Fig. 2B).

Serum TTR level and prognosis. Candidates for independent predictors of prognostic factors (age, <75 vs. $\geq 75$; sex, male vs. female; T1 vs. $\geq$ T2; lymph node metastasis negative vs. positive; lymphatic invasion negative vs. positive; blood vessel invasion negative vs. positive; serum albumin, $<3.5 \mathrm{mg} / \mathrm{dl}$ vs. $\geq 3.5 \mathrm{mg} / \mathrm{dl}$; CRP, $<0.3 \mathrm{mg} / \mathrm{dl} \mathrm{vs.} \geq 0.3 \mathrm{mg} / \mathrm{dl}$; NLR: $<4.5$ vs. $\geq 4.5$; TTR, $\geq 22 \mathrm{mg} / \mathrm{dl}$ vs. $<22 \mathrm{mg} / \mathrm{dl}$ ) were subjected to univariate and multivariate analysis using a Cox proportional hazard model.

Patient characteristics according to the serum TTR level are summarized in Table II. The mean age of the patients with TTR $<22 \mathrm{mg} / \mathrm{dl}(66.6 \pm 9.0$ years $)$ was significantly higher than that of the patients with TTR $\geq 22 \mathrm{mg} / \mathrm{dl}$ ( $75.0 \pm 7.7$ years) $(\mathrm{P}=0.005)$. In addition, the incidence of abnormal CEA levels, albumin $<3.5 \mathrm{mg} / \mathrm{dl}$ and CRP $>0.3 \mathrm{mg} / \mathrm{dl}$ was significantly higher in the patients with TTR $<22 \mathrm{mg} / \mathrm{dl}$ than in the patients with $\mathrm{TTR} \geq 22 \mathrm{mg} / \mathrm{dl}(\mathrm{P}=0.042,0.004$ and 0.022 , 
Table II. Patient characteristics according to transthyretin level.

\begin{tabular}{|c|c|c|c|c|c|c|}
\hline \multirow[b]{2}{*}{ Characteristics } & \multicolumn{3}{|c|}{ Total patients $(\mathrm{n}=42)$} & \multicolumn{3}{|c|}{ Operated patients $(n=35)$} \\
\hline & $\begin{array}{c}\mathrm{TTR} \geq 22 \\
(\mathrm{n}=31)\end{array}$ & $\begin{array}{c}\text { TTR }<22 \\
(\mathrm{n}=11)\end{array}$ & $\begin{array}{c}\text { P-value } \\
(\mathrm{n}=26)\end{array}$ & $\begin{array}{c}\mathrm{TTR} \geq 22 \\
(\mathrm{n}=9)\end{array}$ & TTR $<22$ & P-value \\
\hline Age & $66.6 \pm 9.0$ & $75 \pm 7.7$ & 0.005 & $64.7 \pm 8.8$ & $74.9 \pm 8.6$ & 0.031 \\
\hline Gender & & & 0.151 & & & 0.121 \\
\hline Male & 16 & 9 & & 11 & 7 & \\
\hline Female & 15 & 2 & & 15 & 2 & \\
\hline Histology & & & 0.483 & & & 0.451 \\
\hline Adeno & 19 & 5 & & 16 & 4 & \\
\hline Squamous & 12 & 6 & & 10 & 5 & \\
\hline Size & $25.7 \pm 9.6$ & $36.3 \pm 17.4$ & 0.078 & $25.5 \pm 8.8$ & $36.6 \pm 16.6$ & 0.061 \\
\hline $\mathrm{T}$ & & & 0.281 & & & 0.220 \\
\hline $\mathrm{T} 1$ & 21 & 5 & & 19 & 4 & \\
\hline$\geq \mathrm{T} 2$ & 10 & 6 & & 7 & 5 & \\
\hline $\mathrm{N}$ & & & 1.000 & & & 1.000 \\
\hline Negative & 20 & 7 & & 16 & 6 & \\
\hline Positive & 11 & 4 & & 10 & 3 & \\
\hline Stage & & & 0.437 & & & 0.694 \\
\hline $\mathrm{I}+\mathrm{II}$ & 24 & 7 & & 19 & 6 & \\
\hline III+IV & 7 & 4 & & 7 & 3 & \\
\hline CEA & & & 0.042 & & & 0.034 \\
\hline$<5.0$ & 24 & 5 & & 21 & 4 & \\
\hline$\geq 5.0$ & 5 & 6 & & 4 & 5 & \\
\hline $\mathrm{SCC}$ & & & 0.206 & & & 0.400 \\
\hline$<1.5$ & 9 & 0 & & 9 & 0 & \\
\hline$\geq 1.5$ & 6 & 2 & & 5 & 1 & \\
\hline Cyfra21-2 & & & 1.000 & & & 1.000 \\
\hline$<3.5$ & 26 & 9 & & 22 & 8 & \\
\hline$\geq 3.5$ & 2 & 1 & & 2 & 0 & \\
\hline ALB & & & 0.004 & & & 0.006 \\
\hline$\geq 3.5$ & 25 & 5 & & 24 & 4 & \\
\hline$<3.5$ & 2 & 6 & & 2 & 5 & \\
\hline CRP & & & 0.022 & & & 0.007 \\
\hline$<0.3$ & 23 & 3 & & 22 & 3 & \\
\hline$\geq 0.3$ & 8 & 7 & & 4 & 6 & \\
\hline NLR & & & 0.243 & & & 0.396 \\
\hline$<4.5$ & 24 & 6 & & 21 & 6 & \\
\hline$\geq 4.5$ & 7 & 5 & & 5 & 3 & \\
\hline Ly & & & & & & 0.711 \\
\hline Negative & NA & NA & & 14 & 4 & \\
\hline Positive & NA & NA & & 12 & 5 & \\
\hline $\mathrm{V}$ & & & & & & 0.432 \\
\hline Negative & NA & NA & & 9 & 5 & \\
\hline Positive & NA & NA & & 17 & 4 & \\
\hline
\end{tabular}

TTR, transthyretin (mg/dl); Adeno, adenocarcinoma; Squamous, squamous cell carcinoma; Size, tumor size (mm); CEA, carcinoembryonic antigen (ng/ml); SCC, squamous cell carcinoma antigen (ng/ml); Cyfra, cytokeratin-19 fragment (ng/ml); ALB, albumin (g/dl); CRP, C-reactive protein (mg/dl); NLR, neutrophil-to-lymphocyte ratio; Ly, lymphatic vessel invasion; V, blood vessel invasion; NA, not applicable.

respectively). There were no other significant differences in the demographics between the patients with TTR $\geq 22 \mathrm{mg} / \mathrm{dl}$ and TTR $<22 \mathrm{mg} / \mathrm{dl}$. Regarding the operated 35 patients, the mean age of the patients with TTR $<22 \mathrm{mg} / \mathrm{dl}(74.9 \pm 8.6$ years) was higher than that of the patients with TTR $\geq 22 \mathrm{mg} / \mathrm{dl}$ (67.4 \pm 8.8 years) $(\mathrm{P}=0.031)$, and the incidence of abnormal CEA levels, albumin $<3.5 \mathrm{mg} / \mathrm{dl}$ and CRP $>0.3 \mathrm{mg} / \mathrm{dl}$ was significantly higher in the patients with TTR $<22 \mathrm{mg} / \mathrm{dl}$ than 
Table III. Cox proportional hazard model.

A, Overall survival

\begin{tabular}{|c|c|c|c|c|c|c|}
\hline \multirow[b]{2}{*}{ Categories } & \multicolumn{3}{|c|}{ Univariate analysis } & \multicolumn{3}{|c|}{ Multivariate analysis } \\
\hline & HR & $95 \% \mathrm{CI}$ & P-value & HR & $95 \% \mathrm{CI}$ & P-value \\
\hline Age, years & 4.797 & $1.505-15.286$ & $0.008^{\mathrm{b}}$ & 3.775 & $1.098-12.982$ & $0.035^{\mathrm{a}}$ \\
\hline Sex & 0.301 & $0.081-1.113$ & 0.072 & & & \\
\hline $\mathrm{T}$ & 5.823 & $1.745-19.435$ & $0.004^{\mathrm{b}}$ & 7.161 & $1.959-26.172$ & $0.003^{\mathrm{b}}$ \\
\hline $\mathrm{N}$ & 0.975 & $0.311-3.096$ & 0.975 & & & \\
\hline Ly & 0.813 & $0.262-2.522$ & 0.720 & & & \\
\hline $\mathrm{V}$ & 1.003 & $0.302-3.335$ & 0.996 & & & \\
\hline ALB & 1.227 & $0.268-5.624$ & 0.792 & & & \\
\hline CRP & 1.048 & $0.283-3.882$ & 0.944 & & & \\
\hline NLR & 1.731 & $0.468-6.411$ & 0.411 & & & \\
\hline TTR & 3.513 & $1.029-11.993$ & $0.049^{\mathrm{a}}$ & 4.100 & $0.990-16.985$ & 0.052 \\
\hline
\end{tabular}

B, Recurrence free survival

\begin{tabular}{lccccc}
\hline & \multicolumn{3}{c}{ Univariate analysis } & & \multicolumn{2}{c}{ Multivariate analysis } \\
\cline { 2 - 4 } Categories & HR & $95 \%$ CI & P-value & HR & $95 \%$ CI \\
\cline { 5 - 6 } Age, years & 1.444 & $0.452-4.613$ & 0.535 & 1.444 & $0.452-4.613$ \\
Sex & 0.888 & $0.311-2.536$ & 0.825 & 0.888 & $0.311-2.536$ \\
T & 3.482 & $1.194-10.154$ & $0.022^{\mathrm{a}}$ & 3.482 & $1.194-10.154$ \\
$\mathrm{~N}$ & 2.080 & $0.721-6.002$ & 0.176 & 2.080 & $0.721-6.002$ \\
Ly & 1.958 & $0.613-6.253$ & 0.257 & 1.958 & $0.613-6.253$ \\
V & 1.245 & $0.390-3.974$ & 0.711 & 1.245 & $0.390-3.974$ \\
ALB & 0.428 & $0.056-3.278$ & 0.414 & 0.428 & $0.056-3.278$ \\
CRP & 1.726 & $0.574-5.192$ & 0.311 & & $0.013^{\mathrm{a}}$ \\
NLR & 0.718 & $0.160-3.215$ & 0.665 & & $1.223-12.220$ \\
TTR & 3.254 & $1.070-9.896$ & $0.038^{\mathrm{a}}$ & 3.866 & $0.021^{\mathrm{a}}$ \\
\hline
\end{tabular}

${ }^{\mathrm{a}} \mathrm{P}<0.05 ;{ }^{\mathrm{b}} \mathrm{P}<0.01$. Candidates for independent predictors of prognostic factors (age, $<75 \mathrm{vs} . \geq 75$; sex, male vs. female; $\mathrm{T}, \mathrm{T} 1 \mathrm{vs} . \geq \mathrm{T} 2 ; \mathrm{N}$, negative vs. positive; Ly, negative vs. positive; V, negative vs. positive; ALB, $<3.5 \mathrm{mg} / \mathrm{dl}$ vs. $\geq 3.5 \mathrm{mg} / \mathrm{dl}$; CRP, $<0.3 \mathrm{mg} / \mathrm{dl} \mathrm{vs}$. $\geq 0.3 \mathrm{mg} / \mathrm{dl}$; NLR: $<4.5$ vs. $\geq 4.5$; TTR, $\geq 22 \mathrm{mg} / \mathrm{dl}$ vs. $<22 \mathrm{mg} / \mathrm{dl}$ ) were subjected to univariate and multivariate analysis using a Cox proportional hazard model. HR, hazard ratio; 95\% CI, 95\% confidence interval; T, tumor; N, node; Ly, lymphatic vessel invasion; V, blood vessel invasion; ALB, albumin; CRP, C-reactive protein; NLR, neutrophil-to-lymphocyte ratio; TTR, transthyretin.

in the patients with TTR $\geq 22 \mathrm{mg} / \mathrm{dl}(\mathrm{P}=0.034,0.006$ and 0.007 , respectively).

Fig. 3A shows overall survival and Fig. 3B shows recurrence-free survival of the patients. The patients with TTR $<22 \mathrm{mg} / \mathrm{dl}(\mathrm{P}=0.008)$, the patients with $\mathrm{T} \geq 2$, and the patients who were aged 75 years or older showed significantly poorer overall prognoses (Fig. 3A). Furthermore, the patients with TTR $<22 \mathrm{mg} / \mathrm{dl}(\mathrm{P}=0.027)$ and those with $\mathrm{T} \geq 2$ showed significantly poorer recurrence-free survival rates (Fig. 3B). Table III shows the results of prognostic factor analysis using a Cox proportional hazard model. TTR $<22 \mathrm{mg} / \mathrm{dl}, \geq \mathrm{T} 2$ and age $\geq 75$ years were statistically significant in the univariate analysis. In the multivariate analysis, $\geq \mathrm{T} 2 \quad(\mathrm{HR}=7.161,95 \%$ confidence interval, 1.959-26.172, $\mathrm{P}=0.003)$ and age $\geq 75$ years $(\mathrm{HR}=3.775,95 \%$ confidence interval, 1.098-12.982, $\mathrm{P}=0.035$ ) were independent prognostic factors of overall survival. With regard to recurrence-free survival, TTR $<22 \mathrm{mg} / \mathrm{dl}$ and $\geq \mathrm{T} 2$ were statistically significant in the univariate analysis. In the multivariate analysis, TTR $<22 \mathrm{mg} / \mathrm{dl}(\mathrm{HR}=3.866,95 \%$ confidence interval, 1.223-12.220, $\mathrm{P}=0.021)$ and $\geq \mathrm{T} 2(\mathrm{HR}=4.035,95 \%$ confidence interval, 1.341-12.143, $\mathrm{P}=0.013$ ) were independent prognostic factors of recurrence-free survival.

\section{Discussion}

In the present study, the NSCLC patients with serum TTR levels of $<22 \mathrm{mg} / \mathrm{dl}$ showed a poorer overall and recurrence-free survival than those with serum TTR levels of $\geq 22 \mathrm{mg} / \mathrm{dl}$. Although TTR $<22 \mathrm{mg} / \mathrm{dl}$ was not an independent 
A
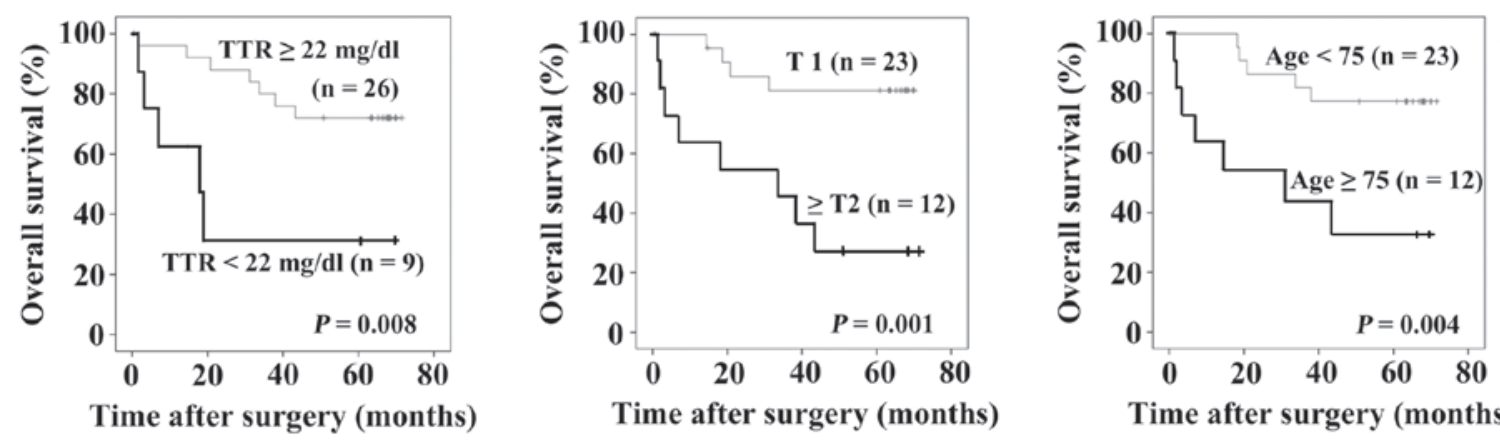

Time after surgery (months)

Time after surgery (months)
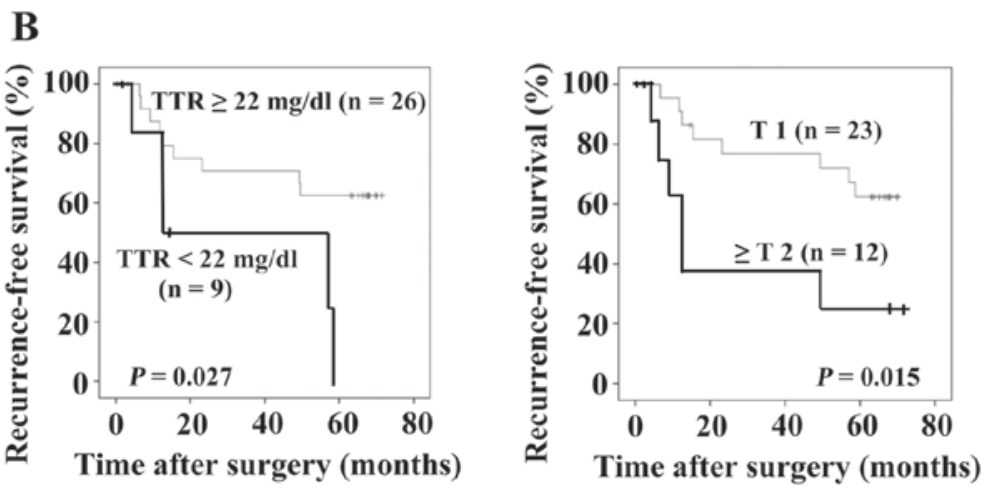

Figure 3. Overall and recurrence-free survival of the patients. (A) Overall survival. The patients with $\mathrm{TTR}<22 \mathrm{mg} / \mathrm{dl}$ ( $\mathrm{P}=0.008$ ), those with $\mathrm{T} \geq 2$ or those aged $\geq 75$ years exhibited significantly poorer overall prognoses. (B) Recurrence-free survival. The patients with transthyretin $<22 \mathrm{mg} / \mathrm{dl}$ ( $\mathrm{P}=0.027$ ) or those with $\mathrm{T} \geq 2$ exhibited significantly poorer recurrence-free survival rates. TTR, transthyretin.

prognostic factor for overall survival, TTR $<22 \mathrm{mg} / \mathrm{dl}$ was an independent prognostic factors for recurrence-free survival. Alifano et al (12) reported that TTR $<28 \mathrm{mg} / \mathrm{dl}$ was one of the independent prognostic factors for overall survival in patients with NSCLC. However, they did not assess recurrence-free survival. Moreover, Kawai and Ota (11) reported that preoperative TTR $<23 \mathrm{mg} / \mathrm{dl}$ and postoperative TTR $<15 \mathrm{mg} / \mathrm{dl}$ was an independent prognostic factor for 2 -year recurrence free survival. Thus, the results of the current study revealed, for the first time, that preoperative TTR was an independent prognostic factor for 5-year recurrence-free survival in NSCLC patients.

The normal function of TTR is to transport thyroxine and RBP/retinol complex in the blood (14). TTR exists in the blood as a homotetramer and contains four tryptophans which are essential amino acids (5). These characteristics make TTR useful in assessing acute phase nutritional condition. As TTR is also a member of rapid turnover proteins, its level is affected by the presence of infections and inflammation. Therefore, serum albumin in combination with CRP, has been used to evaluate a prognosis of cancer patients (4). Recently, however, serum TTR level has been reported to be a prognostic biomarker in various malignancies such as esophageal (15), gastric (16), colorectal (17), pancreatic (18), and renal cancers (19), as well as lung cancer $(11,12)$. Taken together, TTR might be associated with tumor microinflammation, resulting in a poorer prognosis.

With regard to the immunological status in the present study, IL-12 productivity and LMR were lower in the patients with TTR $<22 \mathrm{mg} / \mathrm{dl}$. IL-12 is mainly secreted from antigen presenting cells in response to pathogens, promoting CD4+ cell differentiation into Th1 cells, and enhances the cytotoxic ability of both natural killer and CD8+ T cells (20). On the other hand, lower LMR has been reported to be a useful independent prognostic marker in patients with NSCLC (21). Although higher LMR was firstly reported to be related with favorable prognosis in some hematology malignancies (22), a low pre-treatment LMR seems to represent an unfavorable prognosis in solid tumors (23). In the present study, lymphocyte and monocyte counts showed no statistically significant differences between the patients with TTR $\geq 22 \mathrm{mg} / \mathrm{dl}$ and TTR $<22 \mathrm{mg} / \mathrm{dl}$, while LMR did exhibit a statistical difference. Taken together, decreased IL-12 productivity and lower LMR represent suppressed anti-tumor immunity in the patients with TTR $<22 \mathrm{mg} / \mathrm{dl}$.

A major limitation of the present study is that it includes a small number of NSCLC patients in a retrospective setting. Secondly, not all blood samples were of sufficient volume for all measurements for interleukin productivity. Further research is required to explore the putative association between serum TTR level and prognosis of patients with NSCLS. In conclusion, serum TTR levels, as well as T category, can be useful for predicting the 5-year recurrence-free survival of NSCLC patients. Further studies aimed at discovering nutritional treatments that improve outcomes of patients with NSCLC are warranted.

\section{Acknowledgements}

Not applicable. 


\section{Funding}

No funding was received.

\section{Availability of data and materials}

The analyzed data sets generated during the study are available from the corresponding author upon reasonable request.

\section{Authors' contributions}

TS, MS and HS contributed to the concept, design and integrity of the present study. TI, YO, TY, SM, TH and YS acquired, analyzed and interpreted the data. TS and MS drafted the manuscript and critically revised it for important intellectual content.

\section{Ethics approval and consent to participate}

The present retrospective study was carried out in accordance with the ethical standards of the Ethics Committee of Fukushima Medical University (no. 1095) and with the 1964 Helsinki declaration and its later amendments or ethical standards. Written informed consent was obtained from all enrolled patients. All patient data were treated in accordance with the local privacy regulations.

\section{Patient consent for publication}

Not applicable.

\section{Competing interests}

The authors declare that they have no competing interests.

\section{References}

1. Yoon HI, Kwon OR, Kang KN, Shin YS, Shin HS, Yeon EH, Kwon KY, Hwang I, Jeon YK, Kim Y and Kim CW: Diagnostic value of combining tumor and inflammatory markers in lung cancer. J Cancer Prev 21: 187-193, 2016.

2. Herbst RS, Heymach JV and Lippman SM: Lung cancer. N Engl J Med 359: 1367-1380, 2008.

3. McMillan DC: The systemic inflammation-based Glasgow prognostic score: A decade of experience in patients with cancer. Cancer Treat Rev 39: 534-540, 2013.

4. Osugi J, Muto S, Matsumura Y, Higuchi M, Suzuki H and Gotoh M: Prognostic impact of the high-sensitivity modified Glasgow prognostic score in patients with resectable non-small cell lung cancer. J Cancer Res Ther 12: 945-951, 2016.

5. Spiekerman AM: Nutritional assessment (protein nutriture) Anal Chem 67: 429R-436R, 1995.

6. Caccialanza R, Palladini G, Klersy C, Cena H, Vagia C, Cameletti B, Russo P, Lavatelli F and Merlini G: Nutritional status of outpatients with systemic immunoglobulin light-chain amyloidosis 1. Am J Clin Nutr 83: 350-354, 2006.
7. Rambod M, Kovesdy CP, Bross R, Kopple JD and Kalantar-Zadeh K: Association of serum prealbumin and its changes over time with clinical outcomes and survival in patients receiving hemodialysis. Am J Clin Nutr 88: 1485-1494, 2008.

8. Devakonda A, George L, Raoof S, Esan A, Saleh A and Bernstein LH: Transthyretin as a marker to predict outcome in critically ill patients. Clin Biochem 41: 1126-1130, 2008.

9. Ding H, Liu J, Xue R, Zhao P, Qin Y, Zheng F and Sun X: Transthyretin as a potential biomarker for the differential diagnosis between lung cancer and lung infection. Biomed Rep 2: 765-769, 2014.

10. Hao S, Sun S, Xiao X, He D and Liu L: Selective expression of transthyretin in subtypes of lung cancer. J Mol Histol 47: 239-247, 2016.

11. Kawai $\mathrm{H}$ and Ota $\mathrm{H}$ : Low perioperative serum prealbumin predicts early recurrence after curative pulmonary resection for non-small-cell lung cancer. World J Surg 36: 2853-2857, 2012.

12. Alifano M, Mansuet-Lupo A, Lococo F, Roche N, Bobbio A, Canny E, Schussler O, Dermine H, Régnard JF, Burroni B, et al: Systemic inflammation, nutritional status and tumor immune microenvironment determine outcome of resected non-small cell lung cancer. PLoS One 9: e106914, 2014.

13. Asamura H: Lung, pleural, and thymic tumors. In: TNM Classification of Malignant Tumours, 8th edition. Brierley JD, Gospodarowicz MK and Wittekind C (ed.) John Wiley \& Sons, Ltd., West Sussex, pp105-118, 2017.

14. Sun X, Dyson HJ and Wright PE: Fluorotryptophan incorporation modulates the structure and stability of transthyretin in a site-specific manner. Biochemistry 56: 5570-5581, 2017.

15. Kelly P, Paulin F, Lamont D, Baker L, Clearly S, Exon D and Thompson A: Pre-treatment plasma proteomic markers associated with survival in oesophageal cancer. Br J Cancer 106: 955-961, 2012.

16. Han WX, Chen ZM, Wei ZJ and Xu AM: Preoperative pre-albumin predicts prognosis of patients after gastrectomy for adenocarcinoma of esophagogastric junction. World J Surg Oncol 14: 279, 2016.

17. Fujii T, Sutoh T, Morita H, Katoh T, Yajima R, Tsutsumi S, Asao T and Kuwano H: Serum albumin is superior to prealbumin for predicting short-term recurrence in patients with operable colorectal cancer. Nutr Cancer 64: 1169-1173, 2012.

18. Chen J, Chen LJ, Xia YL, Zhou HC, Yang RB, Wu W, Lu Y, $\mathrm{Hu} \mathrm{LW}$ and Zhao Y: Identification and verification of transthyretin as a potential biomarker for pancreatic ductal adenocarcinoma. J Cancer Res Clin Oncol 139: 1117-1127, 2013.

19. Cai W, Kong W, Dong B, Zhang J, Chen Y, Xue W, Huang Y, Zhou L and Huang J: Pretreatment serum prealbumin as an independent prognostic indicator in patients with metastatic renal cell carcinoma using tyrosine kinase inhibitors as first-line target therapy. Clin Genitourin Cancer 15: e437-e446, 2017.

20. Smyth MJ, Taniguchi M and Street SE: The anti-tumor activity of IL-12: Mechanisms of innate immunity that are model and dose dependent. J Immunol 165: 2665-2670, 2000.

21. Hu P, Shen H, Wang G, Zhang P, Liu Q and Du J: Prognostic significance of systemic inflammation-based lymphocyte-monocyte ratio in patients with lung cancer: Based on a large cohort study. PLoS One 9: e108062, 2014.

22. Porrata LF, Ristow K, Colgan JP, Habermann TM, Witzig TE, Inwards DJ, Ansell SM, Micallef IN, Johnston PB, Nowakowski GS, et al: Peripheral blood lymphocyte/monocyte ratio at diagnosis and survival in classical Hodgkin's lymphoma. Haematologica 97: 262-269, 2012.

23. Nishijima TF, Muss HB, Shachar SS, Tamura K and Takamatsu Y: Prognostic value of lymphocyte-to-monocyte ratio in patients with solid tumors: A systematic review and meta-analysis. Cancer Treat Rev 41: 971-978, 2015. 